\title{
Spectroscopic and Thermooxidative Analysis of Organic Okra Oil and Seeds from Abelmoschus esculentus
}

\author{
Geórgia de Sousa Ferreira Soares, ${ }^{1}$ Vinicius de Morais Gomes, ${ }^{2}$ \\ Anderson dos Reis Albuquerque, ${ }^{3}$ Manoel Barbosa Dantas, ${ }^{3}$ Raul Rosenhain, ${ }^{3}$ \\ Antônio Gouveia de Souza, ${ }^{3}$ Darlene Camati Persunh, ${ }^{2}$ Carlos Alberto de Almeida Gadelha, ${ }^{2}$ \\ Maria José de Carvalho Costa, ${ }^{1}$ and Tatiane Santi Gadelha ${ }^{2}$
}
${ }^{1}$ Departamento de Nutrição, Centro de Ciências da Saúde (CCS), Universidade Federal da Paraíba, 58059-900 João Pessoa, PB, Brazil
${ }^{2}$ Departamento de Biologia Molecular, Centro de Ciências Exatas e da Natureza (CCEN), Universidade Federal da Paraíba, $58059-900$ João Pessoa, PB, Brazil
${ }^{3}$ Departamento de Química, Centro de Ciências Exatas e da Natureza (CCEN), Universidade Federal da Paraíba, 58059-900 João Pessoa, PB, Brazil

Correspondence should be addressed to Tatiane Santi Gadelha, santi.tatiane@gmail.com

Received 29 November 2011; Accepted 12 February 2012

Academic Editor: Salvatore Cuzzocrea

Copyright ( 2012 Geórgia de Sousa Ferreira Soares et al. This is an open access article distributed under the Creative Commons Attribution License, which permits unrestricted use, distribution, and reproduction in any medium, provided the original work is properly cited.

\begin{abstract}
With changes in human consumption from animal fats to vegetable oils, the search for seed types, often from unconventional vegetable sources has grown. Research on the chemical composition of both seed and oil for Brazilian Okra in South America is still incipient. In this study, flour and oil from organic Okra seeds (Abelmoschus esculentus L Moench), grown in northeastern Brazil were analyzed. Similar to Okra varieties from the Middle East and Central America, Brazilian Okra has significant amounts of protein (22.14\%), lipids (14.01\%), and high amounts of unsaturated lipids (66.32\%), especially the oleic (20.38\%) and linoleic acids $(44.48 \%)$. Oil analysis through PDSC revealed an oxidation temperature of $175.2^{\circ} \mathrm{C}$, which in combination with low amounts of peroxide, demonstrates its resistance to oxidation and favors its use for human consumption.
\end{abstract}

\section{Introduction}

The use of vegetable oils instead of animal fats for human consumption has led to unconventional sources and various seeds. Vegetable oils have high amounts of unsaturated fatty acid chains yet no trans fats or cholesterol. The group is of great importance as a source of essential fatty acids and energy [1]. In recent years, the nutritional value of various unconventional foods has been evaluated, and as a result the seeds of many plant species have become alternative lipid sources for human consumption [2, 3]. Among the plants used for vegetable oils, Okra (Abelmoschus esculentus (L) Moench, or Hibiscus esculentus Malvaceae) [4], originating in Africa, and traditionally grown in tropical regions, stands out for its rapid growth cycle, easy cultivation, resistance to pests, high yields, and high nutritional value [5]. Although its cultivation is widespread in northeastern Brazil for having a very favorable climate, research concerning its oil and seeds is still incipient in Brazil.

The procedure for obtaining vegetal oil includes using solvents (chemical methods), and physical methods, or a combination of both. In chemical extraction, a larger amount of oil is usually obtained if compared to mechanical extraction. Degradation of vegetal oils is critical and depends on the concentration of polyunsaturated fatty chains in their composition. It leads to the formation of hydroperoxides, aldehydes, and ketones [6]. Besides reducing nutritional quality, they play an important role in the development of diseases $[7,8]$.

Several methods have been developed for evaluating the oxidative stability of edible oils [9]. Determination is rapid using the accelerated methodology, which was originally proposed for monitoring rancidity. It is known as the Rancimat method [10]. The oxidative process can also be evaluated 
using thermal-analysis techniques such as Thermo-Gravimetric Analysis (TGA), Differential Scanning Calorimetry (DSC), and Pressurized Differential Scanning Calorimetry (PDSC) $[11,12]$. These methods also have the advantages of providing accurate results, low analysis times, and requiring small sample amounts $(<5 \mathrm{mg})[13,14]$ when compared to the Rancimat method. The PDSC method is reproducible and repeatable, being effective both in its dynamic mode, which determines the oxidation temperature of the sample, and in its isothermal mode, when determining the time elapsed from the beginning of oxidation [15]. The objective of this work was to determine the chemical composition of whole organic grain Okra seeds grown in Northeastern Brazil, obtaining and characterizing nutritional value, and the oil's oxidation temperature.

\section{Experimental}

2.1. Plant Material. Organic Okra seeds (Abelmoschus esculentus (L) Moench or Hibiscus esculentus, Malvaceae) were used, obtained from the agroecological fair held at the Federal University of Paraiba and cataloged in the herbarium of that institution under the number JPB 41386.

2.2. Obtaining and Analyzing the Seed Flour. The seeds were manually removed from ripe fruit, dried at $40^{\circ} \mathrm{C}$, selected and milled in a Willey-type electric mill to obtain a fine flour, then submitted to proximate analysis of moisture (weight loss on drying), ash (waste by incineration), lipids (direct extraction in Soxhlet), and of protein (Kjeldahl digestion) [16]. The Anthrone method was used to determine the soluble carbohydrates fraction [17].

2.3. Obtaining and Analyzing the Seed Oil. The seed oil was obtained by extraction with hexane $(1: 20 \mathrm{w} / \mathrm{v})$ in a Soxhlet apparatus for 6 hours. After extraction, the solvent was removed using a rotary evaporator, and the oil was kept in the dark and under $\mathrm{N}_{2}$ atmosphere until the time of analysis. The oil was characterized by peroxide value (PV), gas chromatography (GC/EM), infrared spectrometry (IR), proton magnetic resonance spectrometry (1H NMR), and pressurized differential scanning calorimetry (PDSC).

2.3.1. Peroxide Value $(P V)$. The amount of peroxide was determined according to the method previously described [18]. The sample was dissolved in an acetic acid-chloroform solution, and a saturated solution of potassium iodide and a starch solution at $1 \%$ was added. The iodine released was titrated with thiosulfate sodium until the disappearance of blue.

2.3.2. Gas Chromatography (GC-MS). For the analysis of fatty chains in the oil, a derivation process from triglycerides to methyl esters was carried out according to methodology proposed by Hartman (1973) [19], for subsequent injection into the chromatograph. The tests were performed on a Shimadzu chromatograph, model GC-MS QP 2010, and a Durabond capillary column with a stationary phase DB-5HT
TABle 1: Proximate composition (g/100 g) of seed of Okra seed (Abelmoschus esculentus (L) Moench).

\begin{tabular}{lc}
\hline Component & Average values $\pm \mathrm{SD}^{*}$ \\
\hline Volatile substances at $105^{\circ} \mathrm{C}$ (moisture) & $13.99 \pm 0.02$ \\
Fix mineral residue (ashes) & $4.01 \pm 0.21$ \\
Lipids & $14.01 \pm 0.50$ \\
Fibers & $30.81 \pm 0.31$ \\
Proteins & $22.14 \pm 1.04$ \\
Carbohydrates & $6.69 \pm 0.14$ \\
\hline
\end{tabular}

${ }^{*} n=3$ (analysis in triplicate); SD: standard deviation.

$30 \mathrm{mx}$ with $0.319 \mathrm{~mm} \times 0.10 \mu \mathrm{m}$ of phase thickness. The carrier gas used was helium at a rate of $43.7 \mathrm{~cm} \cdot \mathrm{s}^{-1}$. An aliquot of $1 \mu \mathrm{L}$ of the samples was injected, with an injector temperature of $290^{\circ} \mathrm{C}$ in $1: 50$ split mode. The initial column temperature was $80^{\circ} \mathrm{C}$, followed by two heating stages: $10^{\circ} \mathrm{C} \mathrm{min}-1$, up to $150^{\circ} \mathrm{C}$, and $6^{\circ} \mathrm{C} \mathrm{min}^{-1}$ up to $230^{\circ} \mathrm{C}$, and remaining at that temperature. The analysis time was $50 \mathrm{~min}$. The temperature of the mass detector and the interface temperature was $250^{\circ} \mathrm{C}$, The beginning and end of the $\mathrm{m} / \mathrm{z}$ ratio were 40 and 1000, respectively. The characterization of the fatty acids profiles was made by comparison of the mass spectrum with standards found in the software library (Mass Spectral Database NIST/EPA/NIH). Based on the total area values of the peaks identified, the percentage of fatty esters was quantified in function of the relative area of each peak.

2.3.3. Infrared Spectrometry (IR). The absorption spectrum in the infrared was obtained in a BOMEM MB-102 spectrometer; the sample was deposited on $\mathrm{KBr}$ pellets.

\subsubsection{Proton Magnetic Resonance Spectrometry (1H NMR).} The one-dimensional $1 \mathrm{H}$ NMR spectrum was obtained on a Varian Mercury spectrometer $200 \mathrm{MHz}$, using TMS for internal standard and $\mathrm{CDCl} 3$ as solvent.

2.3.5. Pressurized Differential Scanning Calorimetry (PDSC). PDSC curves (in dynamic mode) were obtained in a DSC 2920 (TA Instrument) with pressure cell, using a platinum crucible, a heating rate of $10^{\circ} \mathrm{C} \mathrm{m^{-1 }}, 1400 \mathrm{kPa}$ of oxygen as purge gas (99.5\% purity and constant volume), temperature range of $25-150^{\circ} \mathrm{C}$, and a sample mass of $5.0 \mathrm{mg}$.

\section{Results and Discussion}

The proximate analysis of the organic Okra seed flour components (Table 1) revealed a predominance of total carbohydrates, represented by insoluble carbohydrates or fibers at $30.81 \%$, and soluble carbohydrates at $6.69 \%$. The values found for macromolecules of incontestable worth in the diet, proteins (22.14\%), and lipids (14.01\%), were similar for Okras from the Middle East [20] and from Central America [21]. The results of the amino acid analysis indicated that Okra seeds are a potential source of protein 


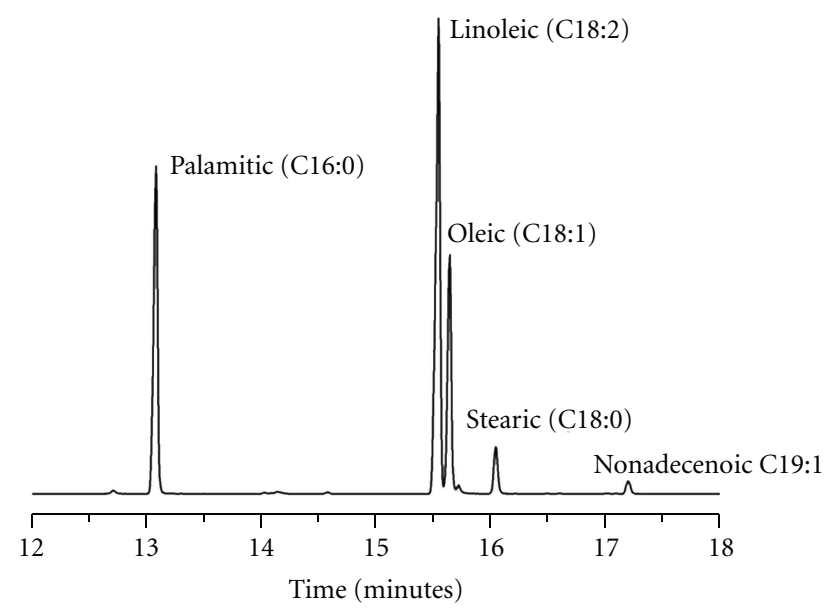

Figure 1: Chromatogram of Okra seed oil obtained by GC-MS. (Only major components are shown.)

and may serve supplementing diets based on cereals in which lysine is usually the first limiting amino acid [21].

The peroxide value (PV) is an indicator for the earlier stages of oxidation. Its value represents the total content of hydroperoxides and is one of the most common indicators of the fats and oils quality during production and storage [22]. The PV value obtained for Okra seed oil was 1.92 meq $\mathrm{kg}^{-1}$, which is low in comparision with the refined olive oil reference in the Codex Alimentarius 1981 (revised-2 in 2003) $[23,24]$ and shows that the chemical extraction process did not degrade the oil, although the system was under reflux for $6 \mathrm{~h}$.

The Okra seed oil chromatogram is shown in Figure 1, and the most intense peaks are identified. Table 2 shows all oil constituents with their respective percentages, and comparisons with the literature. Of the fatty acid chains that compose Okra seed oil, a high linoleic acid chain content was observed at $44.48 \%$, palmitic acid was $28.74 \%$, and oleic acid was $20.38 \%$. The results showed similar compositions for Okra oils grown in Central America, yet they were different from those cultivated in India, in which linoleic acid content is quite low.

Oleic and linoleic acids (omega 6) are among the fatty acids that have a protective effect on the body important to human health, and they are present in Okra oil. Okra seed oil showed similarities to certain oils industrially used for their oleic acid content (corn: $24.8 \%$; linseed: $18.9 \%$; poppy seed: $22.3 \%$; soybean: $23.2 \%$; sunflower seed: $17.7 \%$; walnut kernel: $18.5 \%$ ) and linoleic acid (cottonseed: $57.4 \%$; soybean: 56.2\%; walnut kernel: 56.0\%) [25].

The infrared spectrometry (IR) spectrum of organic Okra seed oil (OSQ) is shown in Figure 2. The identification of all signals was performed according to the literature [26]. The IR spectrum of Figure 2 shows the key signals for the fatty-chain triglycerides of organic Okra oil: stretching $v$ C$\mathrm{H}$ of alkene, $3008.7 \mathrm{~cm}^{-1}$; stretching $v \mathrm{C}-\mathrm{H}$ of alkane, 2923.8 and $2854.4 \mathrm{~cm}^{-1}$; stretching of carbonyl $v \mathrm{C}=\mathrm{O}$ of glycerine ester, $1743.5 \mathrm{~cm}^{-1}$; asymmetric angular deformation $\delta \mathrm{C}-\mathrm{H}$ of alkane, $1458.0 \mathrm{~cm}^{-1}$; symmetric angular deformation $\delta$

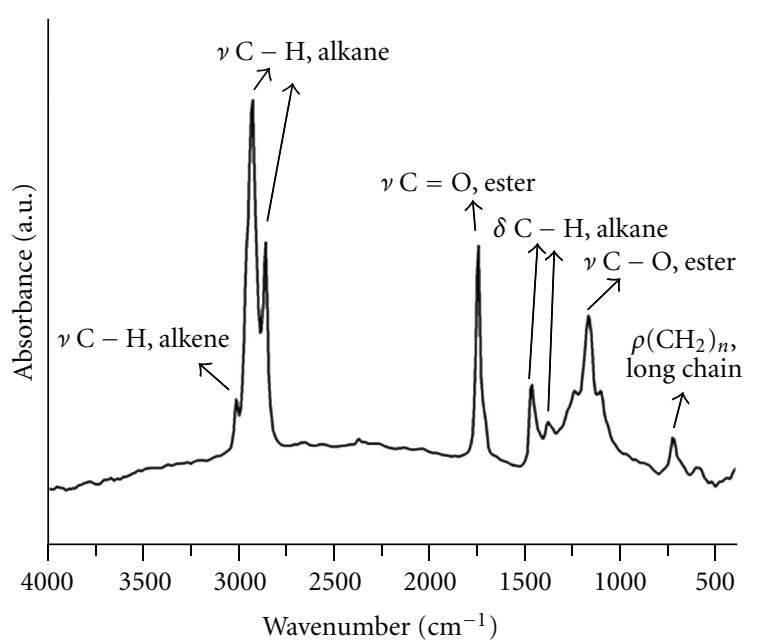

FIGURE 2: Infrared spectrometry (IR) spectrum of the organic Okra seed oil (OSQ).

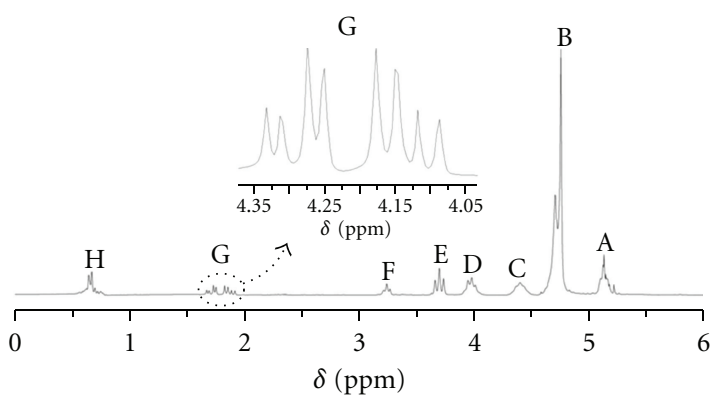

OSQ $\left(\mathrm{H}^{1} \mathrm{RMN}\right)$

FIgURE 3: $\mathrm{H}^{1} \mathrm{NMR}$ spectrum of the organic Okra seed oil.

C-H of alkane, $1373.2 \mathrm{~cm}^{-1}$; stretching $v$ C-O of ester, $1164.9 \mathrm{~cm}^{-1}$; the asymmetric angular deformation $\rho \mathrm{C}-\mathrm{H}$ of alkane, $725.2 \mathrm{~cm}^{-1}$, characteristic of long chains of hydrocarbons $\left(\mathrm{CH}_{2}\right)_{n}$. The absence of signals around $3500.0 \mathrm{~cm}^{-1}$ indicates the low value or absence (at the equipment detection level) of free fatty acids resulting from hydrolysis and/or hydroperoxides, which result from the oxidation of unsaturated chains.

The $\mathrm{H}^{1} \mathrm{NMR}$ spectrum of organic Okra seed oil is shown in Figure 3, where all peaks are identified by a capital letter and identified in Table 3, together with their displacement $\delta(\mathrm{ppm})$ and multiplicity. Nuclear magnetic resonance of hydrogen has been increasingly applied to studies on vegetal oil properties [27], a technique of rapid analysis; it can be used with small quantities of oil "in natura," and without degrading the sample. Unlike chromatography which requires the processing of triacylglycerides into methyl esters, the $\mathrm{H}^{1} \mathrm{NMR}$ technique does not requires previous chemical treatment of the sample and can be used to characterize the glycerine system directly. The identification of all signals was performed in accordance with Vlahov [28]. Starting with the high field signals, a multiplet corresponds to the end 
TABLE 2: Percentage composition of fatty chains present in Okra seed oil obtained by GC/EM methodology.

\begin{tabular}{|c|c|c|c|}
\hline \multirow{2}{*}{ Fatty acid } & \multicolumn{3}{|c|}{ Composition of Okra seed lipids (\%) } \\
\hline & Present study & (Savello, 1980) & (Al-Wandawi, 1983) \\
\hline Myristic (C14:0) & 0.19 & 0.24 & 0.30 \\
\hline Palmitic $(\mathrm{C} 16: 0)$ & 28.74 & 33.72 & 39.14 \\
\hline Palmitoleic (C16:1) & 0.31 & 0.56 & - \\
\hline Estearic $(\mathrm{C} 18: 0)$ & 4.12 & 3.28 & 4.19 \\
\hline Oleic $(\mathrm{C} 18: 1)$ & 20.38 & 17.88 & 55.92 \\
\hline Linoleic $(\mathrm{C} 18: 2)$ & 44.48 & 42.15 & 0.10 \\
\hline Nonadecenoic (C19:1) & 1.15 & - & - \\
\hline Eicosanoic $(\mathrm{C} 20: 0)$ & 0.40 & - & 0.36 \\
\hline Docosanoic (C22:0) & 0.22 & 0.16 & - \\
\hline Others & - & 5.29 & - \\
\hline
\end{tabular}

TABLE 3: Signals of the Okra seed oil spectrum. The hydrogens were classified according to the displacement.

\begin{tabular}{lccl}
\hline Signal & Displacement $\delta(\mathrm{ppm})$ & Multiplicity* & Functional group \\
\hline A & $0.88-0.78$ & $\mathrm{~m}$ & $-\mathrm{CH}_{3}($ saturated $)$ \\
B & $1.27-1.25$ & $\mathrm{~m}$ & $-\left(\mathrm{CH}_{2}\right)_{n}-($ fatty chain $)$ \\
C & $1.60-1.40$ & $\mathrm{~m}$ & $-\mathrm{CH}_{2}(\beta$ to carbonyl $)$ \\
D & $2.05-1.98$ & $\mathrm{~m}$ & $-\mathrm{CH}_{2}($ allylic $)$ \\
E & $2.34-2.27$ & $\mathrm{t}$ & $-\mathrm{CH}_{2}(\alpha$ to carbonyl $)$ \\
F & $2.79-2.73$ & $\mathrm{t}$ & $-\mathrm{CH}_{2}($ bis-allylic $)$ \\
G & $4.32-4.08$ & ddd & $-\mathrm{CH}_{2}$ (glycerine $)$ \\
H & $5.09-5.36$ & $\mathrm{~m}$ & $-\mathrm{CH}$ (vinylic) e $-\mathrm{CH}$ (glycerine) \\
\hline
\end{tabular}

${ }^{*}$ Multiplicity: doublet (d), double doublet (ddd), triplet (t), and multiplet $(\mathrm{m})$.

methyls of the fatty chains in $\delta=0.88-0.78$. In $\delta=1.27-$ 1.25 , the strongest signal of the spectrum, a multiplet on the sequence of methylene hydrogen $-\left(\mathrm{CH}_{2}\right)_{n}$ - was observed. In the field a little lower, the multiplet generated by the hydrogen $\beta$ to the carbonyl at $\delta=1.60-1.40$ is observed. The signal in $\delta=2.05-1.98$ refers to allylic hydrogens, present in unsaturated fatty chains. In $\delta=2.34-2.27$, there is a welldefined triplet, with a coupling constant of $J=7.33 \mathrm{~Hz}$, referring to the $\alpha$ hydrogens and to carbonyl. The signal in $\delta=2.79-2.73$ is characteristic of bisallylic hydrogens, appearing at low field due to the demasking effect of two adjacent unsaturations present in the linoleic fatty chain. The hydrogens generating this last signal received much attention as they are the most susceptible to oxidation in triglycerides. The most characteristic signals of triglycerides in $\mathrm{H}^{1} \mathrm{NMR}$ spectra appeared at $\delta=4.32-4.08$ in the form of a double doublet, referring to hydrogens $\mathrm{H}-1$ and $\mathrm{H}-3$ of the glycerin portion. The $G$ signal is shown expanded in Figure 3. The vinyl hydrogens $-\mathrm{CH}=\mathrm{CH}-$ of unsaturated compounds appear in the spectrum as a multiplet in $\delta=5.09-5.36$, unresolved and overlapping the signal of hydrogen $\mathrm{H}-2$ of the triglyceride glycerol portion. Although the configuration of the double bond $\mathrm{C}=\mathrm{C}$ can be determined by the coupling constant of the vinyl hydrogen (which is always higher for trans bonds than for cis bonds), in practice this is not possible due to the small difference between the chemical shifts of the signals and overlap with the signal of the glycerine
H-2 hydrogen, an overlap unfavorable to the analysis. No signal for oxidation product was observed in the $\mathrm{H}^{1} \mathrm{NMR}$ spectrum, corroborating PV and IR data.

The OT (oxidative temperature) is defined as the temperature at which a rapid increase in the oxidation rate is observed [29], which is obtained by extrapolation of the line tangent to the slope of the exothermic signal in the heat flow versus temperature curve.

The PDSC curve of the organic Okra seed oil is shown in Figure 4(a). The OT and Tp (peak temperature) are shown in Figure 4(b). The profile of the curve shows several exothermic peaks above $175.2^{\circ} \mathrm{C}$. Several studies with various fatty acids, esters from fatty acids, and edible oils [13, 30, 31] show that the first peak of the DSC curve in a nonisothermal method can be interpreted as the formation of peroxides, and the other peaks as decomposition or other oxidative processes. The autoxidation mechanism is shown in Figure 5. Susceptibility to autoxidation is related to several factors, light, heat, oxygen, and metals exposure, yet the fatty chain structure is one of the most important. The greater the number of bisallylic hydrogens in the triglycerides of an oil, the more susceptible to oxidation it will be. They are sites for initiation of the autooxidative process, as shown in Figure 5. Recent studies with fatty acid esters patterns, when submitted to PDSC analysis in dynamic mode [14], show the influence of length, ester content and group type, fatty chains orientation, and the location of double bonds on oxidative 


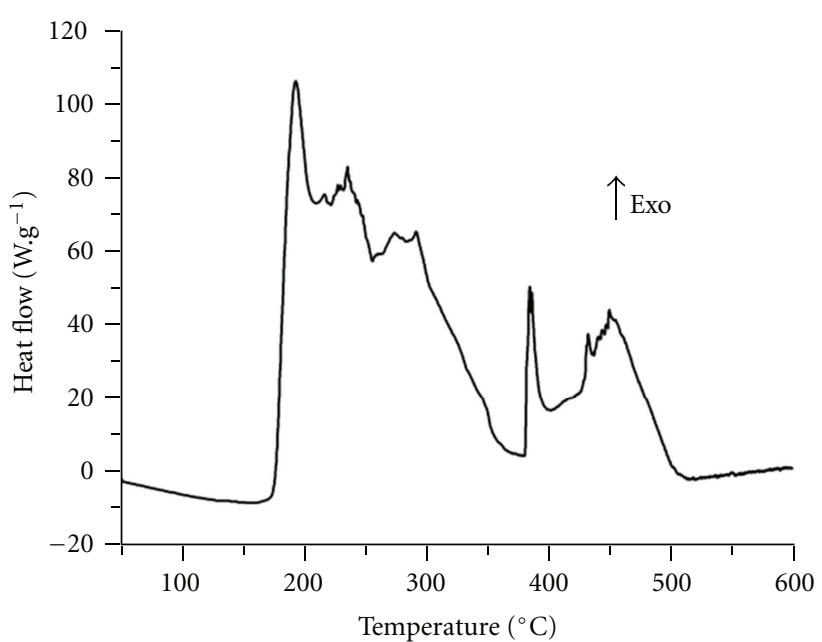

(a)

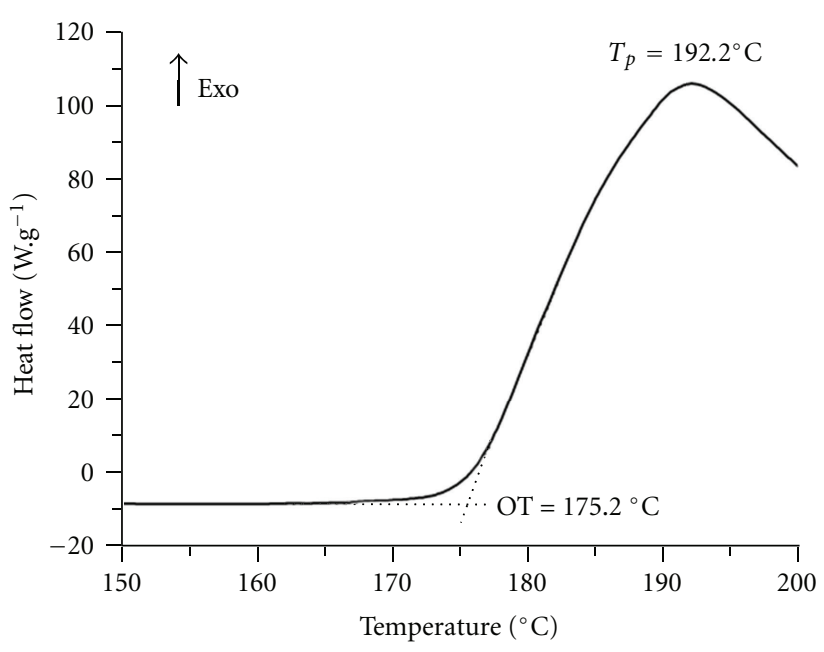

(b)

FIgURE 4: PDSC curve of the organic Okra seed oil (a). OT and $T_{p}$ (peak temperature) (b).

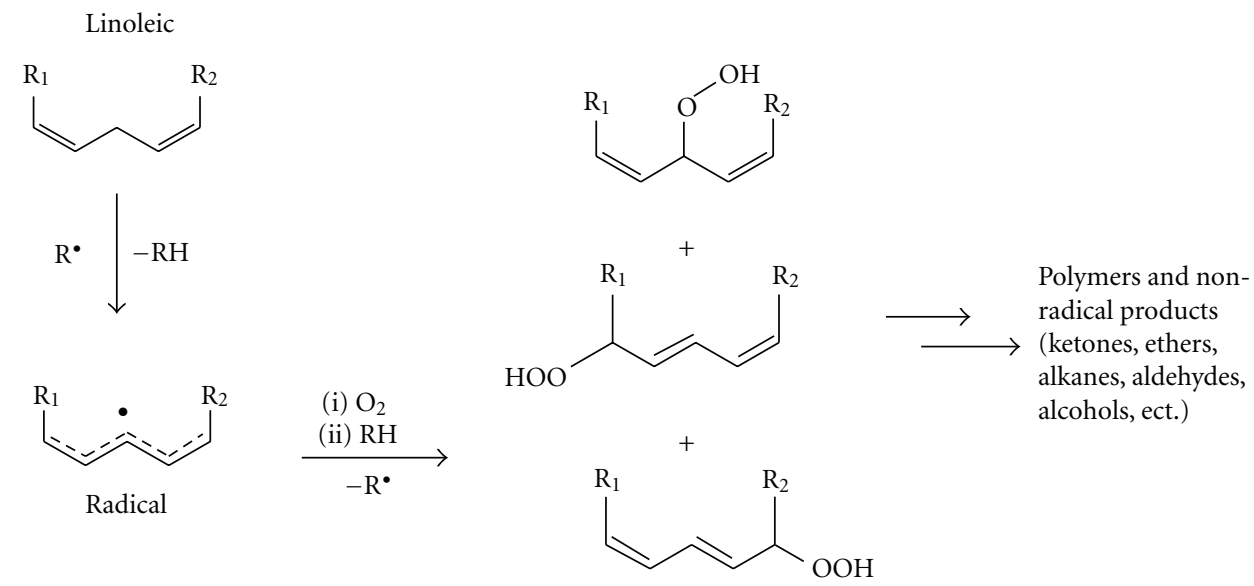

Hydroperoxides

FIgURE 5: Autoxidation mechanism of lipids.

stability. Methyl linoleate, oleate, and palmitate showed OT $\left({ }^{\circ} \mathrm{C}\right)$ equal to $142.6,174.9$, and 198.4, respectively. By analogy and with an appropriate approach, one would expect an intermediate OT value between 142.6 and $198.4^{\circ} \mathrm{C}$ for Okra oil. Although DSC has already been used in the study of autoxidation of pure triacylglycerides [32], no studies were found applying the PDSC methodology.

\section{Conclusion}

The chemical composition was obtained for organic Okra seeds (Abelmoschus esculentus L Moench) grown in northeastern Brazil. They were shown to be a good source of protein and lipids. Brazilian Okra is similar to native Okra from the Middle East and Central America, yet differs from Middle Eastern Okra as to the nature of its lipids. Brazilian Okra is similar to industrially used consumable oils, such as soybean oil when considering both oleic and linoleic acids, which are essential for human health. The extraction method used to obtain the oil secured its integrity, forming few peroxides, and therefore maintaining a high oxidation temperature. The high degree of unsaturations in the oil favors its use for consumption, or for use in the pharmaceutical and chemical industries.

\section{Acknowledgments}

The authors wish to acknowledge the National Council for Scientific and Technological Development (CNPq) for financial support. The authors also thank Dr. Rita Baltazar de Lima of the Department of Botany, UFPB, and PIBIC fellow Cínthia Menezes Lima Ramos Araújo for identifying and cataloging the plant species under study. 


\section{References}

[1] J. L. Harwood, A. Cryer, M. I. Gurr, and P. Dodds, "Medical and agricultural aspects of lipids," in The Lipid Handbook, F. D. Gunstone, J. L. Harwood, and F. B. Padley, Eds., Chapman \& Hall, 2nd edition, 1994.

[2] S. C. Achinewhu, "Unconventional sources of food: chemical composition of rubber seed (Hevea brasiliensis)," Food Chemistry, vol. 21, no. 1, pp. 17-25, 1986.

[3] M. A. Hossain, U. Focken, and K. Becker, "Evaluation of an unconventional legume seed, Sesbania aculeata, as a dietary protein source for common carp, Cyprinus carpio L," Aquaculture, vol. 198, no. 1-2, pp. 129-140, 2001.

[4] G. S. Jamieson and W. E. Baughman, "Okra seed oil," The Journal of the American Chemical Society, vol. 42, no. 1, pp. 166-170, 1920.

[5] S. Calisir, M. Ozcan, H. Haciseferogullari, and M. U. Yidiz, "A study on some physico-chemical properties of Turkey okra (Hibiscus esculentus, L.) seeds," Journal of Food Engineering, vol. 68, pp. 73-78, 2005.

[6] M. D. Guillen and E. Goicoechea, "Oxidation of corn oil at room temperature: primary and secondary oxidation products and determination of their concentration in the oil liquid matrix from ${ }^{1} \mathrm{H}$ nuclear magnetic resonance data," Food Chemistry, vol. 116, no. 1, pp. 183-192, 2009.

[7] I. Staprãns, J. H. Rapp, X. M. Pan, D. A. Hardman, and K. R. Feingold, "Oxidized lipids in the diet accelerate the development of fatty streaks in cholesterol-fed rabbits," Arteriosclerosis, Thrombosis, and Vascular Biology, vol. 16, no. 4, pp. 533-538, 1996.

[8] A. Kanazawa, T. Sawa, T. Akaike, and H. Maeda, "Dietary lipid peroxidation products and DNA damage in colon carcinogenesis," European Journal of Lipid Science and Technology, vol. 104, no. 7, pp. 439-447, 2002.

[9] E. N. Frankel, "In search of better methods to evaluate natural antioxidants and oxidative stability in food lipids," Trends in Food Science and Technology, vol. 4, no. 7, pp. 220-225, 1993.

[10] H. Hadorn and K. Zurcher, "Zurbestimmung der oxidations stabilitat von olenund fetten," Deustsche Ledensmittel Rundschau, vol. 70, no. 2, pp. 57-65, 1974.

[11] C. D. Gamlin, N. K. Dutta, N. R. Choudhury, D. Kehoe, and J. Matisons, "Evaluation of kinetic parameters of thermal and oxidative decomposition of base oils by conventional, isothermal and modulated TGA, and pressure DSC," Thermochimica Acta, vol. 392-393, pp. 357-369, 2002.

[12] C. P. Tan, Y. B. Che Man, J. Selamat, and M. S. A. Yusoff, "Comparative studies of oxidative stability of edible oils by differential scanning calorimetry and oxidative stability index methods," Food Chemistry, vol. 76, no. 3, pp. 385-389, 2002.

[13] G. Litwinenko and T. Kasprycka-Guttman, "A DSC study on therm oxidation kinetics of mustard oil," Thermochimica Acta, vol. 319, pp. 185-191, 1998.

[14] B. R. Moser, "Comparative oxidative stability of fatty acid alkyl esters by accelerated methods," Journal of the American Oil Chemists' Society, vol. 86, no. 7, pp. 699-706, 2009.

[15] D. R. Kodali, "Oxidative stability measurement of high-stability oils by pressure differential scanning calorimeter (PDSC)," Journal of Agricultural and Food Chemistry, vol. 53, no. 20, pp. 7649-7653, 2005.

[16] Instituto Adolfo Lutz, "Métodos físico-químicos para análise de alimentos," in Odair Zenebon; Neus Sadocco Pascuet, P. Tiglea, Ed., Instituo Adolfo Lutz, São Paulo, Brazil, 4th edition, 2008.
[17] E. W. Yemn and A. J. Willis, "The estimation of carbohydrates in plant extracts by anthrone," The Biochemical Journal, vol. 57, no. 3, pp. 508-514, 1954.

[18] AOCS, Official and Tentative Methods of the American Oil Chemists Society, American Oil Chemists Society, Champaign, Ill, USA, 3rd edition, 1980.

[19] L. Hartman, Rapid Preparation of Fatty Acid Methyl Esters from Lipids, vol. 494, Laboratory Practice, London, UK, 1973.

[20] H. Al-Wandawi, "Chemical composition of seeds of two okra cultivars," Journal of Agricultural and Food Chemistry, vol. 31, no. 6, pp. 1355-1358, 1983.

[21] P. A. Savello, F. W. Martin, and J. M. Hill, "Nutritional composition of okra seed meal," Journal of Agricultural and Food Chemistry, vol. 28, no. 6, pp. 1163-1166, 1980.

[22] A. Ruíz, M. J. A. Cañada, and B. Lendl, "A rapid method for peroxide value determination in edible oils based on flow analysis with fourier transform infrared spectroscopic detection," Analyst, vol. 126, no. 2, pp. 242-246, 2001.

[23] Codex Alimentarius Commission, Standard for Olive Oils and Olive Pomace Oils, vol. 8, CODEX STAN 33, 1981.

[24] http://www.codexalimentarius.net/web/standard_list.jsp.

[25] A. Demirbaş, "Fuel properties and calculation of higher heating values of vegetable oils," Fuel, vol. 77, no. 9-10, pp. 11171120, 1998.

[26] R. M. Silverstein, G. C. Bassler, and T. C. Morrill, Spectrometric Identification of Organic Compounds, John Wiley \& Sons, New York, NY, USA, 5th edition, 1991.

[27] Y. Miyake, K. Yokomizo, and N. Matsuzaki, "Determination of unsaturated fatty acid composition by high-resolution nuclear magnetic resonance spectroscopy," Journal of the American Oil Chemists' Society, vol. 75, no. 9, pp. 1091-1094, 1998.

[28] G. Vlahov, "Application of NMR to the study of olive oils," Progress in Nuclear Magnetic Resonance Spectroscopy, vol. 35, no. 4, pp. 341-357, 1999.

[29] A. Adhvaryu, S. Z. Erhan, Z. S. Liu, and J. M. Perez, "Oxidation kinetic studies of oils derived from unmodified and genetically modified vegetables using pressurized differential scanning calorimetry and nuclear magnetic resonance spectroscopy," Thermochimica Acta, vol. 364, no. 1-2, pp. 87-97, 2000.

[30] G. Litwinienko, A. Daniluk, and T. Kasprzycka-Guttman, "Differential scanning calorimetry study on the oxidation of C12-C18 saturated fatty acids and their esters," Journal of the American Oil Chemists' Society, vol. 76, no. 6, pp. 655-657, 1999.

[31] G. Litwinienko and T. Kasprzycka-Guttman, "Study on the autoxidation kinetics of fat components by differential scanning calorimetry. 2. Unsaturated fatty acids and their esters," Industrial and Engineering Chemistry Research, vol. 39, no. 1, pp. 13-17, 2000.

[32] G. Litwinienko, "Autooxidation of unsaturated fatty acids and their esters," Journal of Thermal Analysis and Calorimetry, vol. 65, no. 2, pp. 639-646, 2001. 


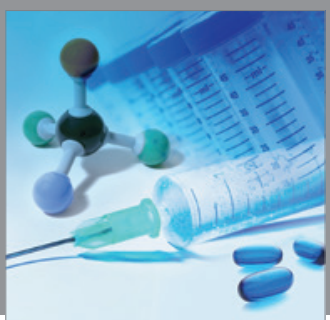

International Journal of

Medicinal Chemistry

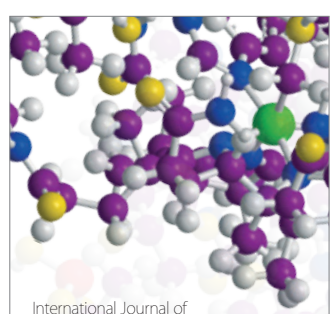

Carbohydrate Chemistry

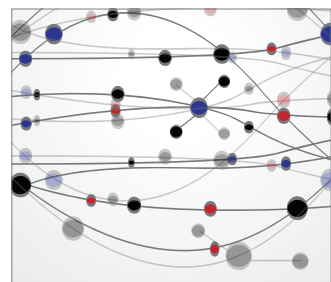

The Scientific World Journal
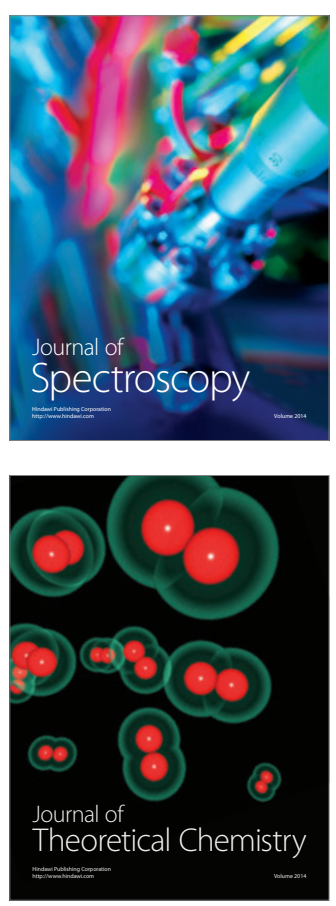
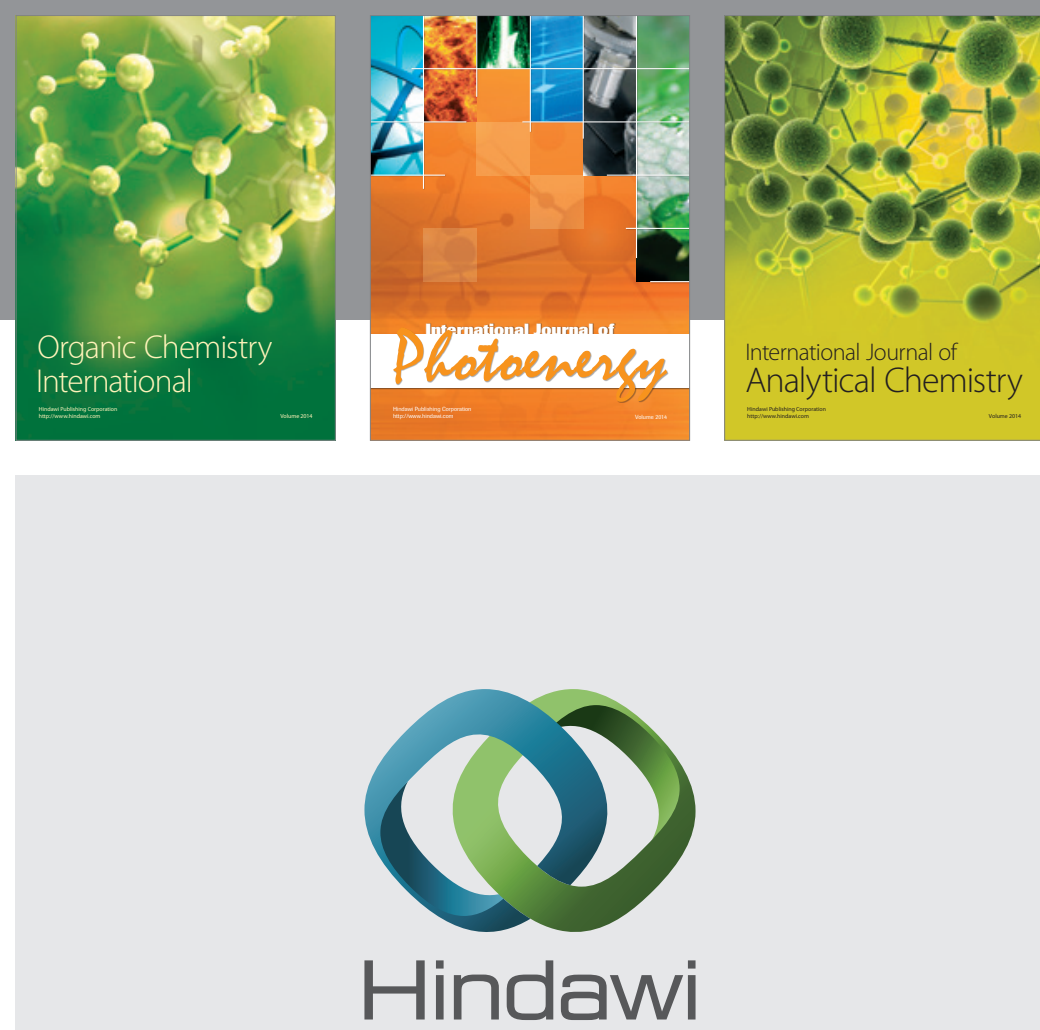

Submit your manuscripts at

http://www.hindawi.com
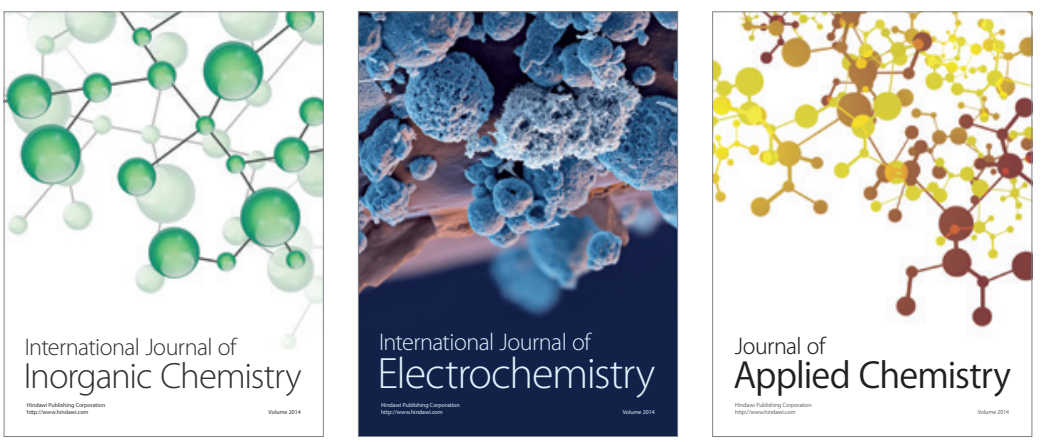

Journal of

Applied Chemistry
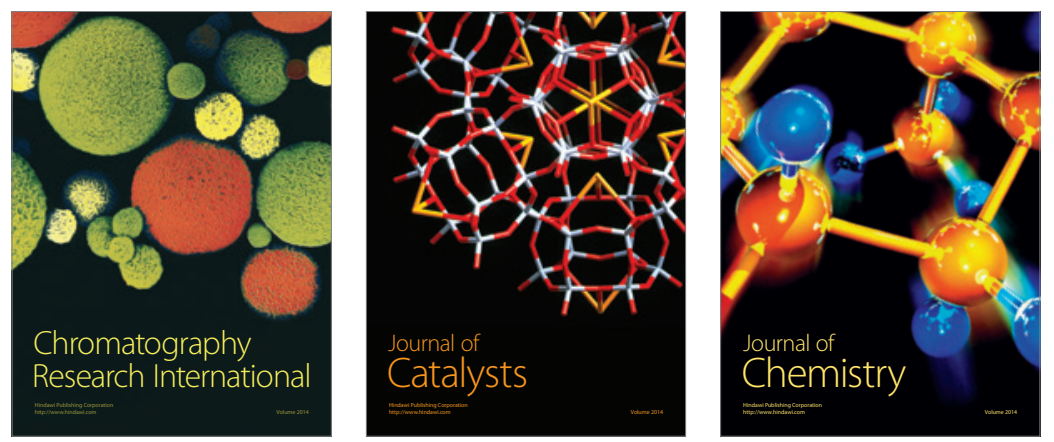
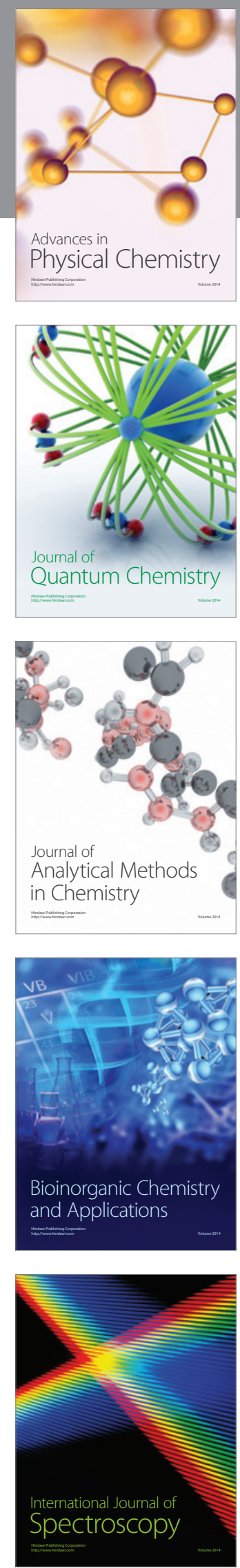